\begin{tabular}{|c|c|c|}
\hline & International Journal of Current Research in \\
Biosciences and Plant Biology \\
\hline EXCELLENT \\
PUBLISHERS
\end{tabular}

\title{
Ethics Bureaucracy against the Health Service at the Health Center of the Town Pare Pare
}

\author{
Rasidin Calundu*
}

Lecturer, Sekolah Tinggi Ilmu Administrasi (STIA), Al Ghazzali Barru, South Sulawesi, Indonesia

\section{*Corresponding author.}

\begin{tabular}{|c|c|}
\hline Abstract & Article Info \\
\hline \multirow{7}{*}{$\begin{array}{l}\text { The study was descriptive in nature so that his analysis is qualitative. The results showed } \\
\text { that the bureaucracy as a State civil servant that served as the Ministry of public health, } \\
\text { which is certainly the attitude and ethics in carrying out the task quite well with attitude } \\
\text { open and clear communication with an emphasis on honesty as a form of professionalism } \\
\text { and commitment, it is embodied with excellent service, quality. Fast, easy, affordable and } \\
\text { scalable. It also needed a friendly service, good communication as an civil servant in the } \\
\text { health field who posed the stance of polite and communicative as the elaboration of } \\
\text { professional values are universal. Communication civil servant in the Ministry of health } \\
\text { has always put forward said the words gentle, well-behaved, polite and fair and trustful } \\
\text { with the openness it is certainly responsiveness civil servant in pretty good health care } \\
\text { with empathy becomes increasingly conducive atmosphere. All of which are highly } \\
\text { associated with the application of ethics in health care at the clinic. }\end{array}$} & $\begin{array}{l}\text { Accepted: } 10 \text { May } 2017 \\
\text { Available Online: } 06 \text { June } 2017\end{array}$ \\
\hline & Keywords \\
\hline & Ethics \\
\hline & Bureaucracy \\
\hline & The public service-health centers \\
\hline & \\
\hline & \\
\hline
\end{tabular}

\section{Introduction}

The crucial problem faced by the Government as a public service, is the emergence of the view of society towards the low performance of the public service bureaucracy, especially the behavior of the civil servant in giving good service as the civil servant that served as a public service of the appropriate moral values to society in various fields. This is related to the implementation of Act No. 25 of 2009 about public service, then the bureaucracy of government continually reform themselves in order to support program management performance-based State civil servant.

Bureaucratic reforms Government that led to the improvement of effective governance and excellence in the future. Since it began to reform the bureaucracy, especially when the bureaucracy of public service in the Department/Agency environment. The Government realizes the importance of good governance, especially performance-based personnel management setup urgently implemented, which given the greater demands of society will lead to a welfare service that promises to become a candidate in the era of globalization which is full of challenge and competition with the introduction of the autonomy of the region.

Bureaucratic setup of linkages with organizations, of course not be detached from the basic elements namely ethics in carrying out the task of health care, especially 
within the world Organization is no exception in government organization of clinics of the city to Parepare. This ethic was not only a regular communication, but in this case required the existence of effective communication i.e. communication that is capable of producing a change in attitude (attitude change) against people involved in the communication, which of course is built on the belief system and the system of value or manners which led to ethics based on the prevailing norms.

The ethics of bureaucrats will become meaningful when we can put ourselves in the situation and condition based on a system of trust and value system itself is encased in ethics-based local wisdom. If these two things can be controlled and we appreciate it, then we will easily do your interactions with anyone and anywhere, especially in carrying out the task as a bureaucracy-oriented public service.

This became a very important benchmark, to see if a bureaucracy capable of creating ethics in carrying out the task, which can provide a link to the community served that need service. That relationship may be evident from the leadership process that is able to influence in determining the objectives of the Organization, motivate the behavior of a person to achieve a goal, affect to improve group and culture.

Some reality at the bureaucrats of the Ministry, especially the bureaucrats in an area that the public services have yet to achieve maximum results. It is assumed as a result of the performance of the service has not been fullest, especially on aspects of the behaviour and attitude of the Government civil servant that is less attentive to the moral principles in the conduct of its work, such as deeds and actions, both in a moral, honest, fair, and the value equation. Government civil servant as a servant of the community still looking issues about the ethics of bureaucracy, i.e., morality as an element that is less concerned with the world of public service.

This fact takes place continuously until today. Assumptions while fenomenology is due to the attitude and behavior of the service of the civil servant is no longer based on local wisdom values as the Foundation of morality in the conduct of the consideration and action in carrying out tasks in civil servant.

The service is the responsibility of the Government as a man of the State civil servant and the man of the people, the main Health Authorities to give satisfaction in the communities it serves, but is still often the case of abuse of authority by using its power to suppress or impose appropriate to the community without considering the desires that his duties as stewards of society. The Organization of the public service of the orientation on power makes the bureaucracy of Government further and further from its mission as a public service. The bureaucracy and officials more set himself as ruler rather than as servants of the community. This is bad due to attitude and behavior in public service tends to ignore the aspirations and interests of the community.

\section{PROBLEMS}

How do ethics bureaucracy in health care as well as a determinant factor in the implementation of service bureaucracy in public ethics.

\section{A REVIEW OF THE LITERATURE}

\section{A. Human resources}

Human resource performance is the ability of a person or of an individual, an organization (institutional) or a system to carry out its function or to achieve its objectives effectively and efficiently. This capacity should be seen as the ability to achieve performance, for menghasilkan output-output (output) and the results (outcomes). According to Tjiptoherijanto (in Celviana Winidyaningrum, 2009) in Alimbudiono \& Fidelis convent (in Celviana Winidyaningrum, 2009), to assess the performance and quality of human resources in melaksanakansuatu functions, including accounting, can be seen from the level of responsibility and competence resources.

Responsibility can be seen in deskripsijabatan. Description of the Office is the basis for carrying out the task denganbaik. In the absence of a clear position description, these resources can do it his duties properly. While the competence can be seen darilatar behind education, training and skills of the yangdinyatakan in the execution of the task. Competence is a characteristic someone who has the skills (skill), knowledge (knowledge) and ability to execute a job (Hevesi in Celviana Winidyaningrum, 2009).

Competence is the underlying characteristics of the person reaches a high performance in his work. 
Employees who do not have enough knowledge in the works will meet many obstacles that result in waste of materials, time and effort. Skill is required to carry out the capacity of a set of tasks that developed from the results of training and experience. According to Hevesi (Celviana Winidyaningrum, 2009) one's skill is reflected of how well someone in carrying out a specific activity such as operating a piece of equipment, communicate effectively or implementing a business strategy.

\section{The concept of human resource management}

Human resource management in other terms is often called: "personal management"; "personal administration" resources administration" (Umi Sukamti in Brian Nuryanta, 2008). Some of those terms in the field of education is one of the substance of education management. To clarify the concept of human resource management, the author may need to display multiple views of experts as follows.

Edwin B. Flippo (1984) stated that human resource management is the process of planning, organizing, direction and control of the procurement workforce, compensation, development, integration, maintenance and termination of employment relationships with a view to achieving the objectives or target individuals, organizations, and communities.

According to Haneman (Rasel Mahmud Nuryanta, 2008) States that: "the Personal or human resources management is a set of organization-wide functions or activities that are designed to influence the activities if the employees in the organization". Meanwhile, according to Wayne and Elias (in Brian Nuryanta, 2008) "human resources management is the attraction, selection, retention, development and utilization of human resources in order to achieve both individual and organization objectives".

\section{Human resource management functions}

Human resource management is deskripsi essentially of administration or management education identificate his functions as a setting of one administrative or management education designed untuksaling deals between individual and organizational goals. According to Castetter (Rasel Mahmud Nuryanta, a 2008) administrative or management process tersebutmeliputi planning, recruitment, selection, induction, appraisal, development, compensation, bargaining, security, continuity, andinformation. While Randall (Rasel Mahmud Nuryanta, 2008) identifies the functions to the human resource in the process include "planning, staffing, appraising, andtraining compensation".

Of some definitions and concepts of human resource management on top of it is understood that a human resources management is a process that is related with implementate indicator functions of management or manajemenyang plays an important role and effectively support the tercapainyatujuan individual, institution, or organization or company.

For an organization, resource management human has related the overall Affairs of the Organization and objectives of the after emphize. For that all the components or elements in it i.e. the Manager with a variety of activities should focus on the planning of composestaff, that concern the determination of the exercise program office and others. It need done to anticipate the development of a long term pendekdan term of such an organization, especially its human resources readiness has conected. Another reason is that a human resources management within an organization can not be detached from the internal and external environment, which at some point will be able to affect the existence of the organization.

\section{B. Employee performance}

Someone will always crave the respect for the results of the improvements and expect a fair reward. Evaluation of performance needs to be done seobyektif maybe because would motivate employees in doing kgiatannya. Beside that also evaluation the performance can provide information for the purposes of the granting of salary, promotions and view the behavior of employees.

Waldman (in h. Koesmono Friends, 2005); the performance is a combination of behavior with the accomplishment of what was expected and the choice or the terms of an existing task in each individual in the organization. Whereas according to the Mangkunegara (in h. Koesmono Friends, 2005); performance can be defined seb Cascio (in h. Koesmono Friends, 2005) says that the performance is a feat of employees of tuganya. Soeprihantono (in h. Koesmono Friends, 2005); said that the performance was the result of work of an employee during a specific pereode in comparison with the various possibilities, for example, standard, object/criteria have been determined in advance and agreed upon together. 
A variety of types of work performed by the employee, of course need criteria are obvious, because each job, surely have different standards of achievement of results. The more complicated types of work, then standard operating procedure set out will be an absolute requirement that must be followed.

Performance is the behavior of an organization that is directly related to the production of goods or the delivery of services. Information on organizational performance is a very important thing used to evaluate whether the process performance of organizations for this is already in line with the expected destination or not. But in reality, many organizations are thus less or even not rarely anyone has information about performance in the organization.

Performance as the results of the job function/activity of a person or group in an organization that is affected by a variety of factors to achieve the objectives of the organization within a specific time period (Tika, 2006). While according to Rivai and Basri (2005) performance is the willingness of a person or group of people to do something and refine it in accordance with the responsibilities with the results as expected.

\section{Job satisfaction}

Basically that someone in work will feel comfortable and high on companies his loyalty when in his work gain job satisfaction according to what you want. Particularly in Companies manufacturing job satisfaction is highly coveted by all parties, as in the company's manufacturing activities starting from procurement of raw materials to become goods so fraught with challenges both physical as well as psychological. Job satisfaction itself actually has significance for what a worker?

There are two words that is satisfaction and work. Satisfaction is something the feeling experienced by someone, where what is expected has been fulfilled or even what the expected all received, while the work is a person want to take destination with earn income or compensation from his contributions to his work.

Dole and Schroeder (in h. Koesmono Friends, 2005); Job satisfaction can be defined as heart and individual reactions to environmental work, while according to Testa and Locke (in h. Koesmono Friends, 2005); Job satisfaction is or statement positive emotions excitement results from the assessment of one of the or experience jobs-job experience. Nasarudin, Igalens and Roussel (in h. Koesmono Friends, 2005); Job satisfaction may be as a pleasurable ar positive emotional state resulting from the appraisal of one's job or job experiences. In a statement has meaning that job satisfaction is an emotional state can be fun or posive resulting from a evaluation job or a person's work experiences.

Ward and Sloane (in h. Koesmono Friends, 2005); elements of job satisfaction: (1) relationship withcolleagues; (2) relationship with the head of department;(3) ability and efficiency ofhead of the department; (4) hours of work; (5) the opportunity to use initiative; (6) Promotion prospects; (7) the salary; (8); job security; (9) the actual work undertaken; (10) the overall job satisfaction. Research of Linz (in $h$. Koesmono Friends, 2005); saying that there is work towards positif attitude in a positive relationship with job satisfaction. Basically the more positive attitude of work greater job satisfaction, also various indicators of job satisfaction needs to obtain special attention so we hope could improve its performance. In General a person feels satisfied with satisfied improvements due to work and obtain a fair evaluation from his leader Job satisfaction according to Robbins (Hery and Veronika, 2013) is a common attitude towards the work of a person, the difference between the number of reward received a large number of workers with whom they believe should they receive. Our satisfaction is the work assessment, feeling or attitude of employees towards his work related to the work environment, the types of jobs, compensation, relations between colleague, social relations at work and so on (Koesmono in Hery and Veronika, 2013). So it can be stated that our satisfaction work is the result of the fulfillment of some wants and needs through the activities work.

\section{Research methods}

This type of qualitative research approach through phenomenology

\section{Results and discussion}

Portrait of opaque bureaucracy is the study of the ethics of moral transgressions because of various bureaucratic red tape, bureaucracy is viewed as one of the highly bureaucratic diseases affect public services. This fact that caused the importance of improvement of the 
bureaucracy or more popularly known as the bureaucratic reform in the face of the pathology of the bureaucracy (bureaucratic diseases). The pathology of the bureaucracy is a disease or a form of organizational behaviour that deviate from the value of ethical values, rules and statutory provisions as well as the norms in force in the bureaucracy.

Morality is one viable instruments in a social group requires the presence of a guiding action (action guide) for all behavior patterns called immoral. Then morality will be similar to the law on the one hand and the Convention or ethics on the other hand. Therefore the question of ethics is a moral issue and morality is measured from the side of good and bad for human behavior.

Public ethics is indeed directly related to the public service, especially the issue of public integrity should be done by public officials. Public servants are indispensable responsibility and personal integrity as a public officer, making it capable of running task in accountability and transparency. One of the reasons the importance of public ethics for a variety of reality in organizing government votes of various components in the community that public services are bad terms with conflict of interest, so that may give rise to or undermine the commitment of public officials on ethical values.

The public service is a service of the activities implemented by the Government as a man of the State and the community in the framework of efforts the fulfillment of the needs of the community, adjusted according the implementation of the provisions of the legislation. Therefore the community demanded the performance of a quality public service, so that it can meet the needs of society and the welfare of society.

In the era of reform, the Government's efforts in creating a democratic State-oriented governance good governance (good governance) is facing a fairly heavy constraints with various aspects of the challenges faced, specialy related to public policies that have implications for the public service, usually addressed in excess that culminated in the emergence of the problem of corruption, gratification, informal tax and such that plagued the organizers of Government as a public service. The effort takes the country into a State of good governance with emphasis on transparency, accountability, legal certainty and participatory society with based on humanitarian values become stunted and experiencing the issue that is crucial in delivering improved welfare of the community.
The bureaucracy as the spearhead of the organizers of Government inherent functions as functions of the service, the setting, the development and function of empowerment so that largely determine the effort of creating good governance so that needed serious handling, especially in an understanding of the duties and responsibilities as a man of the country as well as the man of the community by providing quality service with emphasis on humanitarian values.

Expectations will be high quality public service of something very important in organizing good governance. Public service based humanity will lead to our satisfaction levels of service to the community against the Ministry civil servant. There are several reasons that cause dissatisfaction of Community Ministry civil servant namely;

1) Any alleged irregularities occurred in the execution of services, 2). The existence of attitudes and behavior in performing the task is considered not appropriate customs and culture of the nation, 3) lack of discipline against the officers on the schedule or time has been specified, 4). The completion of the drawn-out affair and there is no certainty, 5). There was negligence in the use of materials, the workmanship of the goods do not comply with the request or a standard, 6). The given service is less/do not meet the standards, or does not meet the expectations of society, 7). There are rules/danggap service mechanism complicate, incriminating or where reducing/disregard them, and 8). There is no satisfactory response against complaint was submitted.

With regard to the framework of Good Governance, public officials are obliged to give each equal treatment for all citizens in the exercise of the functions of the public Ministry as (Equality before the law). Simply that there are seven strategies in improving the service abbreviated Service, such strategies are:

1) Self-esteem (give a value on yourself), 2). Exceed expectation (beyond the $\mathrm{d}$ To be able to achieve the targets of the service appropriately suggested using the SMART approach: Apecific (specific), Meansurable (scalable), achievable (achievable), relevant (releven) and time-bound (lement with time). Humanitarian values have always been a reference point in the community activity and becomes the value of the civilization that illustrate the character society which will be coloring activity of human life. As a public service, as the civil servant is certainly in the discharge of his duties and 
making its human values as benchmarks in delivering quality services.

The ethics of the public perceive that the means are needed in the public service is to satisfy institutions/social institutions more fairly, which is certainly the main goal the attainment principles satisfy accountability, transparency and neutrality. Therefore, the required settings for the behavior of the community in the face of fundamental issues, including the improvement of the political order and the political forces that are styled in accordance with the principle of fairness, neutrality and transparency.

On the other hand, the ethics of the public highlights of "the Act" public officials who are required to have a public integrity because as the actors play a role and simultaneously determine the political rationality. Concepts about moral values and ethics in government administration formulated to be applied in the life of the Union and the scope of the actual administration. The ethical conception of benefit will only be felt if it can really be a part of the dynamics of modern administration.

A waiter served as an civil servant of the Ministry of the public attitude and communication in the course of carrying out the task quite well. Indeed the communication which is based etiquette by showing a friendly attitude as public service civil servant. As the civil servant of Civil servants, the public service must be able to shown with attitude open and clear communication, it is embodied with excellent service, quality. Fast, easy, affordable and scalable. It also needed a friendly service, good communication as an civil servant in the field of religion that puts attitude courteous and communicative as the elaboration of professional values are universal.

Ethics bureaucracy in public service did not inflate regardless of honesty as the Foundation in communicating. Consistency in putting forward This honesty indicated that turned out to be a means of honesty in the aspect of ethical against the public. Honesty is the main factor in communications as a public service so that the service standard is so easy to implement that will eventually give birth to a quality public services with emphasis on human values as essential values in berinterksi with the community. It is incumbent on health clinics waiter civil servant in task with honesty to put forward as being the substantial value.
The success of the civil servant in carrying out public service tasks are highly associated with ethics with the community so communication civil servant in public services is always put forward the said words are gentle, well-behaved, polite. Consistency in implementing effective ethics is pretty good. It is understood that as the waitress very friendly health authorities conduct effective communication, especially in the public service. Civil servant in carrying out public service able to provide excellent service with effective communication so that the main factor in realizing good communication as spoken words, soft, good behavior and polite and highly noteworthy.

That is not as important in the public service is the principle of Justice is to become a reference with based on compliance and the feasibility of creating a quality service and to give satisfaction to the Public Ministry. With consistently good enough, where healthcare is highly concentrated with the principles of Justice with reference to compliance and eligibility for the elaboration of professionalism. The principle of fairness in public service is essential with reference to compliance and eligibility as an elaboration of the tasks of the civil servant. It is indeed a must for human justice and become the elaboration of human rights as an object of service.

One element in realizing good governance (Good Governance) is transparency (openness), which became the very thing that determine public service quality. The openness of the public Ministry as civil servant have not been fullest. This means that openness in the service of the public is still very weak, given the height percentage is less consistent. It is hampered in doing public service with high quality standards. Indeed openness in the public service to become a thing that step considering his difficult in behavior open in public Ministry due to factors that are not supportive of the quality of the public service. Openness in the public service is becoming a necessity by the civil servant in the service of qualified public displays that include about openness will system, procedure as well as the cost. This has been the antidote against anxiety society will conduct civil servant, especially in public services expands. In addition to that openness can also reduce abuses and CCN so that community satisfaction would be a public service will be realized. A quality service according to Osborne and Gebler (1995), as well as Bloom (1981), among others, have traits such as; not prosudural (bureaucratic), distributed and decentralized, and oriented to the customer. 
As a public service in exercising civil servant charged with all his loyalties in meeting the needs of the community in the public service. Certainly the civil servant in the service of the public is able to give space to the society by getting a quality service with consistency is pretty good. However, the public has not fully given the space to get a quality service with the still high percentage is less consistent. This is because it is still always take refuge on power so that some items of the Ministry are still not optimally so often makes the public feel unfairly treated. Results of interviews indicate that the civil servant responsible certainly able to give space to the community to get a quality service. Indeed the public service performed by the civil servant while upholding human rights. This shows that human rights in the running of public services into something essential, especially for service-based Humanity.

Human rights indeed be something very important in carrying out public services, especially in creating good governance (Good Governance),Surely a quality public service performed by the civil servant, always refer to the rules in force so as to give public servants so that reliability is capable the public service community will. This is quite good, that indeed the reliability of service the public is inseparable from the good management of service standards service standard, although still not optimally. Reliability of service the public is able to give satisfaction in the community, among other things, (1) simplicity in bureaucracy and procedure, (2) the clarity of the provision of services, costs and so on, (3) accuracy in the calculation of cost, time, (4) proof of service in the security, and (5). Ease of access. Besides of course the Ministry as soon as possible to settle the Affairs of the society.

Public services have a high level of resistance because it is very related to the needs and desires of the community who always get fast service with quality, appropriate and capable of reducing the anxiety of the public. Civil servant must have responsiveness in serving the needs of the community in accordance with the expectation with the perception that is pretty good. Responsiveness public service in the civil servant to the people who have needs which vary so that his Ministry is not optimally so surely the level of satisfaction of society will also decrease. Civil servant in dealing with the different needs of society should have the attitude of responsive and sensitive to the needs of the community and not to the maximum.

One of the basic tasks of the State bureaucracy as the civil servant of the man and the man of the community i.e. service public. Indeed increasingly intelligent social conditions will of rights and obligations, especially in getting the services of qualified public, although varied needs. It requires empathy civil servant in providing public services infrastructure. It is simply the maximum. Empathy Government against quite well with the more quality and infrastructure the basic needs of the community. Empathy civil servant in providing public services and infrastructure can be shown, among others, by providing administrative completeness which can facilitate the community, creating an atmosphere that is conducive for the Ministry.

Quality service into something much needed community as a form of good governance with service that shows you the certainty and confidence of the community. With the adequate level, it becomes imperative quality service is the assurance and confidence to be something essential in the public service and simplicity. This gives service an easy and excellent service. This can also be done with the simplicity of the civil servant in the public service makes it easy. This is indeed a very important aparature in socialication with the community by not creating gaps as part of the system of Government. They serve it with is not convoluted by simplifying the process of public service.

There are several aspects that affect public service accountability by bureaucracy is concerned with the moral, human resource aspects, environment and system that shows a pretty good thing. Indeed the ethical and moral became very important in the service of the public. Ethics communication civil servant in public service in addition to being influenced by the values and norms that are applicable in the community as well as by external and internal factors such as personal civil servant and the concerned authorities including the environment management. In addition to that no less important is the public service as a duty, responsibility and mandate.

\section{Conclusion}

Service of the public in its development, its main global challenges have occurred a paradigm shift in the public service:

1) Of problems-based services to rights-based services. Social services which are given merely to respond to the problems or needs of the 
community, are now held to meet the community's social rights as mandated by the Constitution.

2) Of the rules-based approaches to learning outcomes-oriented approaches. The appropriate public service approach shifted from being solely based on normative regulations be approach oriented results. Accountability, effectiveness and efficiency are becoming increasingly important key words.

3) Of public management to public governance. In the concept of public management, the community is considered as a client, customer or user of the service so that it is part of a market contract. Whereas, in the concept of national public, society viewed as citizens who are part of the social contract.

\section{Conflict of interest statement}

Authors declare that there is no conflict of interest.

\section{Bibliography}

Ahmad, Badu, 2008. Kondisi Birokrasi Indonesia Dalam Hubungannya Dengan Pelayanan Publik, Jurnal Administrasi Publik, IV (1), 45-52.

Azhari, 2011. Mereformasi Birokrasi Publik Indonesia, Yogyakarta: Pustaka Pelajar.

Bappenas, 2007. Modul Penerapan Tata Kepemerintahan yang Baik. Jakarta: Sekretariat Tim Pengembangan Kebijakan Nasional Tata Kepemerintahan yang Baik.

Bertens, K., 2011. Etika, Jakarta: PT Gramedia Pustaka Utama.

Bungin, Burhan, 2008. Metodologi Penelitian Kualitatif, Jakarta: Kencana Renada Media Group.

Carino, Ledivina V, 1992. Bureaucracy for Democracy The Dynamics of Executive Bureaucracy Interaction During Govermental Transitions, Philippines: College of Public Administration, International Center for Economic Growth, Philippines Institute for Development Studies.

Celviana Winidyaningrum, 2009. Pengaruh Sumber Daya Manusia dan Pemanfaatan Teknologi Informasi Terhadap Keterandalan dan Ketepatwaktuan Pelaporan Keuangan Pemerintah Daerah Dengan Variabel Intervening Pengendalian Intern Akuntansi (Studi Empiris di Pemda Subosukawonosraten). Program Studi Magister Akuntansi Fakultas Ekonomi Universitas Sebelas Maret Surakarta 2009.
Copeland, L. 1988. "Valuing Diversity: Pioneer and Champions of Change". Personnel. July: 48.

Devito, A. Joseph. 2011. Komunikasi Antarmanusia. Tangerang : Karisma

Devito, Joseph A. 1991. Human Communication, The Basic Course. New York: Harver Collins Publisher, Fifth Edition.

Dwiyanto, Agus, 2008. Reformasi Birokrasi Publik di Indonesiai, Yogyakarta: Gajah Mada University Press.

Effendi., Onong Uchjana. 2003. Ilmu Komunikasi Teori dan Praktek. Bandung: Remaja Rosdakarya.

Fadillah, Syarif \& Darmanto, 2010. Kinerja Aparatur Pemerintah Daerah Dalam Rangka Pelayanan Publik, Jurnal Ilmu Administrasi Negara, X (2), 192-203

Fernanda, Desi, 2003. Pengembangan Kualitas Pelayanan Publik di Daerah, Jurnal Administrasi Publik, II (2), 191-193.

Flippo B. Edwin. (1984). The Personnel Management. Mc Graw Hill Book Company.

H.Teman Koesmono, 2005. Pengaruh Budaya Organisasi Terhadap Motivasi dan Kepuasan Kerja Serta Kinerja Karyawan Pada Sub Sektor Industri Pengolahan Kayu Skala Menengah di Jawa Timur. Jurnal Manajemen \& Kewirausahaan, Vol. 7, No. 2, September 2005.

Hammer, M., dan J. Champy. 1993. Reengeenering The Corporation: A Manifesto forBusiness Revolution. New York: Harper Business.

Haryatmoko, 2011. Etika Publik Untuk Integritas Pejabat Publik dan Politis, Jakarta: PT Gramedia Pustaka Utama.

Hery dan Veronika, 2013. Pengaruh Motivasi Terhadap Kinerja Pegawai Dengan Variabel Pemediasi Kepuasaan Kerja Pada PDAM Kota Madiun. Jurnal Riset Manajemen dan Akuntansi (JRMA); Vol. 1 No. 1, Februari 2013

Isworo, Walujo Iman, 2007. Akuntabilitas, Responsibilitas dan Etik Dalam Administrasi Publik, Jurnal Bisnis \& Birokrasi, XV (1), 836-848

Judge, T. A., Erez, A., \& Bono, J. E. (1998). The power of being positive:The relationship between positive self-concept and job performance. Human Performance, 11, 167-187.

Keban, Yeremias T. 2008. Enam Dimensi Strategis Administrasi Publik Konsep, Teori dan Isu, Yogyakarta: Gava Media.

Kumorotomo, Wahyudi, 2008. Akuntabilitas Birokrasi Publik Skestsa Pada Masa Transisi, Yogyakarta: Pustaka Pelajar.

Lena Ellitan, 2001. Praktik-Praktik Pengelolaan Sumber Daya Manusia danKeunggulan 
Kompetitif Berkelanjutan. Jurnal Manajemen \& Kewirausahaan Vol. 4, No. 2, September 2002.

Manahan. 2008. Perilaku Keorganisasian. Bogor: Ghalia Indonesia

Morissan. 2009. Teori Komunikasi Organisasi. Jakarta: Ghalia Indonesia

Muchlas, Makmuri. 2005. Perilaku Organisasi. Yogyakarta : Gadjah Mada University Press.

Muhammad Arni. 2009. Komunikasi Organisasi. Jakarta : PT. Bumi Aksara

Muhtar, Entang Adhy, 2010. Pelayanan Publik di Indonesia Dalam Perspektif Kultural, Jurnal Administrasi Negara, I (1), 17-24

Muis RMS, Asdar dkk., 2012. Mata Air Peradaban. Yogyakarta: Citra Pustaka.

Mulyana, Deddy. 2005. Ilmu Komunikasi: Suatu Pengantar. Bandung : Remaja Rosdakarya.

Nanang Nuryanta, 2008. Pengelolaan Sumber Daya Manusia(Tinjauan Aspek Rekrutmendan Seleksi). Jurnal Pendidikan Islam, NO. 1. VOL. I. 2008.

Noor, Abduh, 2008. Ethics, Religion and Goog Governance, Jurnal JOAAG, III (2), 62-77.

Pace, Wayne \& Faules, Don. 2010. Komunikasi Organisasi. : Strategi Meningkatkan Kinerja Perusahaan. Bandung : PT Remaja Rosdakarya.

Pangarsa, Galih Widjil, 2006. Pemberdayaan SDM Berwawasan Kearifan Lokal Menuju Pembangunan Lingkungan Binaan Berkelanjutan, Jurnal Ilmiah Administrasi Publik, VII (1), 450-462

Pattimukay, Hengky V.R., 2008. Peranan Administrasi Publik Dalam Pembangunan Sosial Pemberdayaan Masyarakat, Jurnal Hipotesa, II (2), 79-88.

Pramusinto, Agus dan Erwan Agus Purwanto, 2009. Reformasi Birokrasi, Kepemimpinan dan Pelayanan Publik. Yogyakarta: Gava Media. Publishing Group.

Pujiastuti Shintya. 2009. Pentingnya Pertanyaan dalam Proses Pembelajaran. Diambil dari: http://www.sdinatalenta.com/arsipartikel/artikel_tya.pdf. Diakses tanggal: 18 Mei 2012.

Purwanto, Ngalim. 1990. Psikologi Pendidikan, Cet. V; Bandung : Remaja Rosdakarya

Rivai, Veithzal dan Basri. 2005. Performance Appraisal: Sistem Yang Tepat UntukMenilai Kinerja
Karyawan Dan Meningkatkan Daya Saing Perusahaan. PT RAJAGRAFINDO PERSADA. Jakarta.

Said, Mashadi. 2007. Kearifan Lokal dalam Sastra Bugis Klasik, Jurnal Proceeding PESAT, II (2), 14-22.

Setyowati, Sulis, 2008. Membangun Tata Pemerintahan dan Pelayanan Publik Dalam Mewujudkan Good Governance, Jurnal LIKITHAPRADNYA, I (2), 104115.

Sinambela, Lijan Poltak. 2010. Reformasi Pelayanan Publik, Teori, Kebijakan, dan Implementasi, Jakarta: Bumi Aksara.

Surjadi. 2009. Pengembangan Kinerja Pelayanan Publik, Bandung: PT.Refika Aditama.

Suryadi, 2010. Analisis Motivasi Birokrasi Dalam Pelayanan Publik, Jurnal Ilmiah Administrasi Negara, X (2), 181-191.

Suryono, Agus. 2011. Manajemen Sumber Daya Manusia, Etika dan Standar Profesional Sektor Publik, Malang: Universitas Brawijaya Press.

The Liang Gie. 1989. Etika Administrasi Pemerintahan, Yogyakarta: Yayasan Studi Ilmu dan Tknologi Yogyakarta.

Tika, P. 2006. Budaya Organisasi Dan Peningkatan Kinerja Perusahaan. PT Bumi Aksara. Jakarta.

Timothy A. Judge and Joyce E. Bono, 2001. Relationship of Core Self-Evaluations Traits-SelfEsteem, Generalized Self-Efficacy, Locus of Control, and Emotional Stability - With Job Satisfaction and Job Performance: A Meta-Analysis. Journal of Applied Psychology 2001, Vol. 86, No. 1, 80-92

Walker, J.W. 1990. "Managing Human Resources in a Flat, Lean, and Flexible Organization: Trends for The 1990's". Human Resource Planning. Vol. 11: 125-132.

Weber, Max, 1964. The Theory of Soscial and Economic Organization, The United States of America: The Free Press.

Zeithaml, Valarie A., A. Parasuraman dan Leonard L. Berry. 1990. Delivering Quality Servicess: Balancing Customer Perceptions and Expectations, New York: The Free Press.

\section{How to cite this article:}

Rasidin Calundu, 2017. Ethics bureaucracy against the health service at the health center of the Town Pare Pare. Int. J. Curr. Res. Biosci. Plant Biol. 4(6), 42-50. doi: https://doi.org/10.20546/ijcrbp.2017.406.005 